\title{
Anecdotal information on dolphin-fisheries interactions based on empirical knowledge of fishers in the northeastern Mediterranean Sea
}

\author{
Androniki Pardalou*, Athanassios C. Tsikliras \\ Laboratory of Ichthyology, School of Biology, University Campus, Aristotle University of Thessaloniki, \\ Thessaloniki 54124, Greece
}

\begin{abstract}
Anecdotal information provided by local fishers is an invaluable tool in the study of marine mammal-fisheries interactions. This paper summarizes empirical and anecdotal information voluntarily provided by fishers during a survey monitoring the damage to coastal fisheries caused by dolphins. We visited 23 fishing harbours along the northern Aegean Sea coastline and monitored the fishing gear of 113 coastal fishers in order to identify the damage caused by dolphins. While we were monitoring the damage, the fishers voluntarily shared their general views on marine mammals and fisheries interactions, which were recorded and are presented here. The majority of fishers indicated that fishing gear, mesh size, depth and target species were important factors that determine depredation frequency and gear damage, whereas soaking time, time of day and season were not considered crucial. These findings provide useful insight in the study of dolphin-fishery interactions, especially for data-poor areas such as the northeastern Mediterranean Sea. The empirical knowledge of the fishers and their views is also important from an ethical perspective because, historically, dolphins in the Mediterranean had been culled and hunted for bounties for many years; even today, occasional deliberate dolphin killings are still recorded. Such information is required in the design of any management strategy that aims to minimize the conflicts with dolphins, thus preserving the fishers' livelihood.
\end{abstract}

KEY WORDS: Dolphin-coastal fishery interactions - Dolphin damage $\cdot$ Fisheries management • Coastal fishery $\cdot$ Northern Aegean Sea

\section{INTRODUCTION}

Fisher experience and knowledge is an important source of information for the study of fisheries complexity and should be taken into account during the design of fisheries management strategies (Johannes et al. 2000). Especially when spatiotemporal constraints apply, along with limitations in human resources and funding, fishers' empirical knowledge can provide baseline data that may reveal issues and patterns (Maynou et al. 2011), act complementary to (Bevilacqua et al. 2016) or even contradict existent scientific data (Gaspare et al. 2015).

${ }^{*}$ Corresponding author: apardalou@bio.auth.gr
Interactions between dolphins and coastal fisheries is a 'hot' issue of increasing concern in the Mediterranean Sea, with economic, social and ethical implications that further complicate fisheries management. Moreover, apart from important fisheries data that are also poor in the Mediterranean (Dimarchopoulou et al. 2017), it is imperative to improve scientific knowledge on dolphin population dynamics and behaviour patterns, especially with respect to fisheries. Many marine mammal-fisheries interaction studies, which usually require extensive human resources and funding and are often spatiotemporally constrained, rely solely on information derived from fishers or are combined with field

(C) The authors 2018. Open Access under Creative Commons by Attribution Licence. Use, distribution and reproduction are unrestricted. Authors and original publication must be credited. 
observations (López et al. 2003). Most of these studies provide insight on issues that may not be observed in the field, such as dolphin behaviour around nets, levels of dolphin incidental catches, economic loss due to damage of the fishing gear and potential management solutions (Díaz López 2006, Goetz et al. 2014).

Information on the interactions between coastal fisheries and dolphins in the Greek seas is limited to the Ionian Sea (Bearzi et al. 2010) and adjacent areas (Amvrakikos Gulf: Piroddi et al. 2011, Gonzalvo et al. 2015; Korinthiakos Gulf: Bonizzoni et al. 2016) and the Thracian Sea (Mitra et al. 2001, Milani et al. 2013). For 3 yr we have been working on dolphincoastal fishery interactions along the northern Aegean coastline (northeastern Mediterranean Sea), aiming to identify the factors that affect depredation frequency by monitoring the actual damage to the fishing gear at the landing ports, along with the characteristics and target species of the gear. Alongside this research, we have come into personal contact with the coastal fishers, who voluntarily shared their empirical knowledge and various anecdotal facts and figures, all of which were recorded. Thus, in the present work we summarize all information derived from those informal conversations, aiming to reveal the attitudes of fishers towards dolphins, which can be useful in ecosystem-based fisheries management and local fisheries management plans, including the potential compensation of fishers for damage suffered and income lost.

\section{MATERIALS AND METHODS}

\section{Northern Aegean Sea}

The northern Aegean Sea (Fig. 1), is one of the most productive marine areas in the eastern Mediterranean Sea, due to nutrient inflows coming from the Black Sea, the influence of river discharges from mainland northern Greece, the increased eutrophic status of the semi-enclosed Thermaikos Gulf, the extended continental shelf and the northerly winter winds that predominate during the summer months (Papaconstantinou \& Farrugio 2000, Bosc et al. 2004). It is an important fishing ground for small and medium-sized pelagic fishes, such as the European pilchard Sardina pilchardus, the European anchovy Engraulis encrasicolus and horse mackerels (Trachurus spp.), but also for demersal stocks, like red mullets (Mullus spp.), grey mullets (Family Mugillidae) and European hake Merluccius merluccius, as well as for flatfishes (Family Soleidae) (Stergiou et al. 2007).

\section{Empirical knowledge and anecdotal information}

Fishers' empirical knowledge was incidentally collected during a wider research project on dolphincoastal fisheries interactions, by monitoring the damage caused by dolphins on the fishing gear. For this primary project we visited 23 fishing ports on the

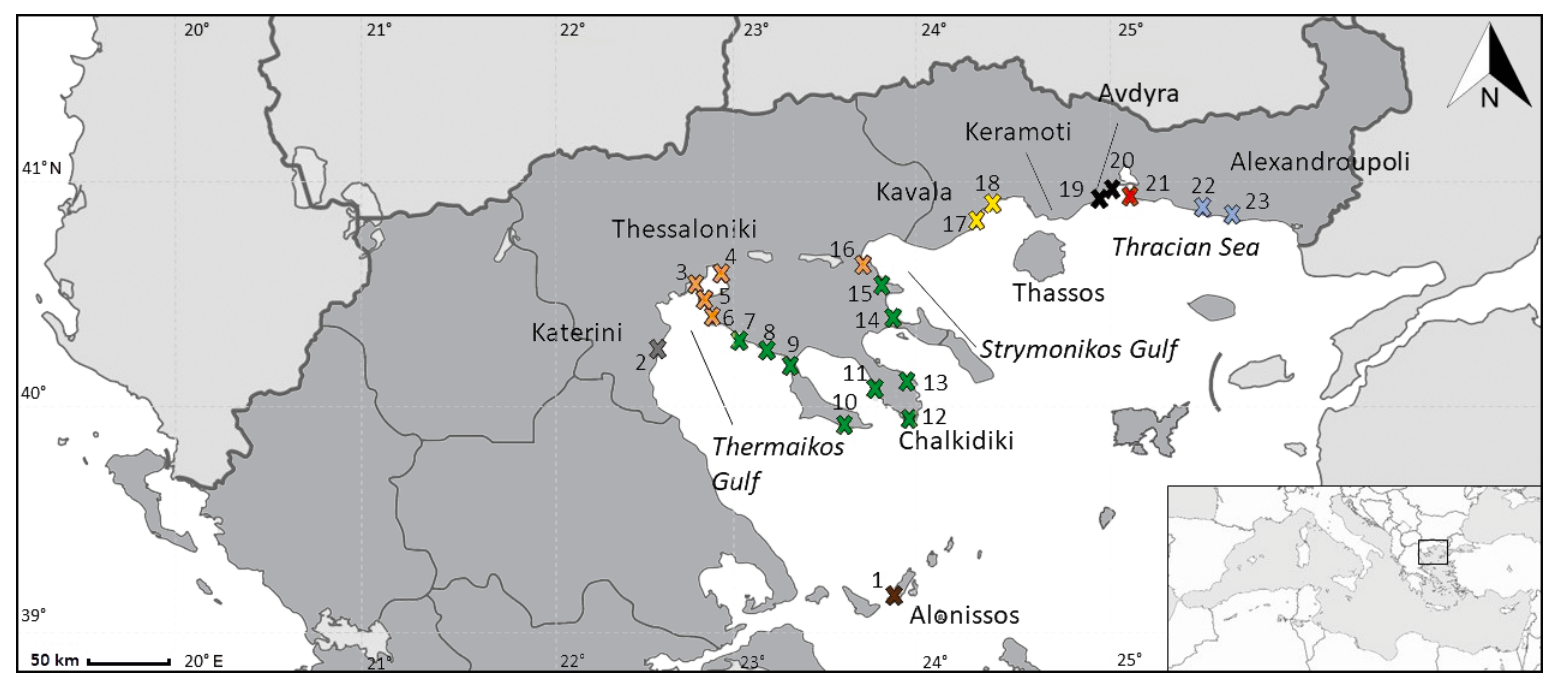

Fig. 1. Northern Aegean Sea, indicating the 23 fishing harbours visited (crosses) in 8 areas (respective colouring). From bottom and left to right the fishing harbours were 1: Patitiri-Alonissos, 2: Katerini, 3: Chalastra, 4: Krini-Thessaloniki, 5: Aggelochori, 6: N. Michaniona, 7: N. Kallikratia, 8: N. Moudania, 9: Potidea, 10: N. Skioni, 11: N. Marmaras, 12: Porto Koufo, 13: AchladaSarti, 14: Ierissos, 15: Olympiada, 16: Stavros, 17: Central-Kavala, 18: Sfagia-Kavala, 19: Avdyra, 20: Porto-Lagos, 21: Fanari, 22: Central-Alexandroupolis and 23: Maistros-Alexandroupolis 
northern Aegean Sea, from November 2013 to February 2016 and monitored the damage to the fishing gear deployed by 113 fishers (Fig. 1). The surveyed fleet included all small-scale coastal fishery vessels that operated nets (gill nets, trammel nets, combined nets, small encircling nets), longlines (drifting and set longlines) and traps (mainly fyke nets and pots) as primary or secondary registered gear in the Common Fisheries Registry (CFR; European Commission 2014).

Throughout the primary project, data on the type of fishing activities (such as gears used, target species and fishing grounds) were acquired. During the informal conversations that followed, fishers shared their experiences with respect to the factors they thought were affecting depredation risk, offered an estimate of depredation frequency and evaluated the ensuing gear damage and respective economic loss. They also revealed the measures they had previously adopted to eliminate conflicts with dolphins and made suggestions for the future. The discussions were informal; no questionnaire was used. All fishers were shown an identification catalogue of the dolphin species known to inhabit the waters of the northern Aegean Sea and were asked to distinguish the ones interacting with their fishing activities. The northern Aegean Sea provides suitable habitats for 4 dolphin species: common bottlenose dolphin Tursiops truncatus, short-beaked common dolphin Delphinus delphis, Risso's dolphin Grampus griseus and striped dolphin Stenella coeruleoalba (Frantzis 2007). Harbour porpoises Phocoena phocoena are rare in the northern Aegean Sea and are confined to areas east of Thassos Island (Cucknell et al. 2016).

\section{RESULTS AND DISCUSSION}

\section{Marine species interacting with coastal fisheries}

Among the 4 species of dolphins present in the waters of the northern Aegean Sea, all fishers were able to distinguish bottlenose dolphins from the other species shown in the identification catalogue, and indicated bottlenose dolphins as the species primarily interacting with coastal fisheries. Common dolphins were also reported as interacting with coastal fisheries. Only 1 fisher operating in the Thracian Sea (Port of Avdyra) reported systematically catching harbour porpoises as incidental catches in trammel nets targeting common sole Solea solea, in the area between Thassos Island and Keramoti (Fig. 1). Indeed, the marine area to the north of Thassos Island is one of the 'hot spots' for harbour porpoise occurrence in the northeastern Mediterranean sea, its distribution being confined within the $150 \mathrm{~m}$ depth contour (Cucknell et al. 2016).

According to the literature, bottlenose dolphins interact with coastal fisheries because of their more coastal distribution (Frantzis 2007) and catholic diet (Blanco et al. 2001). Secondarily, common dolphins are also involved in the conflicts with coastal fisheries, showing some overlap in diet and spatial distribution with bottlenose dolphins, although common dolphins are more mesopelagic feeders and can be found at all depths (Cañadas et al. 2002). In Greek waters, bottlenose and common dolphin distribution is usually confined within the $250 \mathrm{~m}$ depth contour (Frantzis 2009); thus, the chances of interacting with coastal fisheries are higher.

In agreement with fishers' empirical knowledge, dolphins tend to cause large irregular holes or tears in the nets, a pattern that greatly differs from the type of damage inflicted by other predators (e.g. net damage by Mediterranean monk seals Monachus monachus is usually associated with a characteristic 3hole pattern: Berkes et al. 1979). Nevertheless, other actively swimming animals, human-related activities or damage due to contact with hard substratum may also produce the same damage pattern. Linking damage type to dolphins requires attention and can be examined preferably by direct visual methods or by indirect inference based on the correlation between damage type occurrence and dolphin presence (Reeves et al. 2001).

Apart from dolphins, fishers indicated a variety of other species, mainly marine mammals, reptiles and seabirds, that interact with coastal fisheries. The most problematic interaction especially for the fishers operating in the Thracian Sea (Fig. 1) involved the invasive blue crab Callinectes sapidus. Additionally, marine reptiles such as loggerhead turtles Caretta caretta, green sea turtles Chelonia mydas and leatherback turtles Dermochelys coriacea were reported to inflict great damage to nets, but also to longlines. Depredation by Mediterranean monk seals on static nets as well as longlines was mentioned as a frequent and disturbing event only by the fishers operating in areas of higher seal density (outer Thermaikos Gulf, Chalkidiki and Alonissos Island). Furthermore, fishers of coastal areas near river mouths (western Thermaikos Gulf) and deltas (Nestos River) also reported limited interaction with Eurasian river otters Lutra lutra. Other marine species such as large pelagic fishes (swordfish Xiphias gladius and tunas Thunnus spp.) and small sharks (e.g. Scyliorhinus spp. and Galeus spp.) were also reported to depre- 
Table 1. General grouping of fisher behaviour as either inflexible (invariable fishing behaviour throughout the year) or adaptive (altering fishing gear and grounds, depending on weather, season, target species, catchability, dolphin depredation) in the northern Aegean coastal fishery, along with the main characteristics of each group

\begin{tabular}{|ll|}
\hline Inflexible & Adaptive \\
\hline Narrow range of gears & Wide range of gears \\
Few target species & Multiple target species \\
Selected fishing grounds & Multiple fishing grounds \\
Rigid to change & Able to change tactics according to circumstances \\
Usually perceive dolphins as threat & Usually consider themselves as intruders \\
In favour of culling campaigns or state bounties & Believe humans are to blame due to overfishing \\
\hline
\end{tabular}

date and cause damage both to nets and longlines. Lastly, seabirds such as white-headed gulls (Larus spp.) were reported to depredate from nets and longlines.

\section{Fishing tactics and measures to minimize depredation}

Based on their fishing tactics and our conversations with them, fishers were separated into 2 main groups: 'inflexible' and 'adaptive' (Table 1). Unresponsive fishers included those operating a very narrow range of gear types, with the same target species throughout the year, and adaptive fishers included those who used a wide range of gear types, visiting multiple fishing grounds, mainly depending on season, weather, target species of interest and catchability, as well as dolphin occurrences, which they tried to avoid.

All fishers maintained that dolphins (predominantly bottlenose dolphins) mainly interact with passive gear, specifically static bottom nets (gill and trammel nets). Dolphins were considered by almost one-third of the fishers as 'pests', most commonly accused of contributing to the declining fish stocks, damaging the nets by creating large holes and tears, spoiling and devaluating the catch. The fishers added that dolphins are 'picky choosers', mainly taking commercially important species, such as red mullets, European hake and common sole. Dolphins have been reported in the literature as 'eating too much' (Đuroviç et al. 2017, p. 427), consuming tons of commercially important fish species, ostensibly reducing the available stocks for the fishery (Reeves et al. 2001).

The fishers reported that overfishing and subsequent fish stock depletion is the primary driver for the intensification of dolphin-fisheries interactions observed during the last decade. They also claimed that dolphin populations have increased dramatically over the past years and some considered culling activities an appropriate and the most effective measure to mitigate all conflicts (Bearzi et al. 2004, Gonzalvo et al. 2015). Historically, as fish stocks declined, culling campaigns and state bounties have been 'traditionally' incorporated in many parts of the world, in areas of overlap between fisheries and dolphins, aiming to reduce conflicts, benefit fish stocks and ultimately commercial fisheries (see Bowen \& Lidgard 2013 for a detailed review on marine mammal culling campaigns). In the Mediterranean, a state bounty for dolphins was issued in 1865 by the French government, though with little success (Anonymous 1989), whereas Italy and former Yugoslavia also issued rewards for dolphin takes in the 19th and, more systematically, the 20th century in the Adriatic Sea (Crnkovic 1958). In Greece, newspaper clippings from the early 20th century present dolphins (and whales) as 'gluttonous monsters', usually hunted down and killed, whereas at least since 1961 and until 1982 there were successive state bounties in force (Gonzalvo et al. 2015). Among other factors, these targeted hunts of dolphins greatly contributed to dolphin population declines across the Mediterranean Sea (Bearzi et al. 2004).

Compensation for fishing gear damaged by marine mammals was considered an important aid for coastal fisheries. Nevertheless, a small percentage of the fishers $(<5 \%)$ believe that no compensation scheme would be enough to cover the substantial economic losses (with respect to damaged fishing gear, spoiled or depredated catches and the workload required to repair gear instead of fishing), due to the high frequency of interaction that can render nets (especially gill nets) useless within just a few days.

Dolphins were described as notably intelligent animals by the fishers, able to distinguish between different engine sounds, sometimes following a specific vessel from the moment it leaves the port, a behaviour that has been described in the literature (Reeves et al. 2001). Fishers ( $<5 \%)$ who had used pingers in the past as a means of mitigating conflicts stated that pingers were not effective after some 
time and that dolphins eventually became habituated to the signals produced. Studies on pinger effectiveness in mitigating depredation by dolphins have shown contradicting results (Cox et al. 2003, Kastelein et al. 2006, Brotons et al. 2008, Gazo et al. 2008), and in the long run, issues of habituation and the 'dinner-bell' effect do arise (Kraus 1999, Reeves et al. 2001, Cox et al. 2003).

A small portion of fishers (7.2\%) regarded themselves as 'intruders' into the animals' environment. These fishers operated multi-gear, multi-species fisheries (Table 1) and were generally more flexible and adapted their fishing behaviour accordingly. For example, a fisher (Katerini port) stated that he manages to 'save' gillnets targeting surmullet Mullus surmuletus because he chooses to deploy them during May and closer to the shore, after noticing that during that time, when most local fishers operate trammel nets with small mesh size targeting the caramote prawn Melicertus kerathurus, dolphins tend to congregate in those areas of high fishing effort. Dolphins do not show a preference for prawns (Barros \& Wells 1998) but rather for other species bycaught on trammel nets used for prawns, such as surmullet, bogue Boops boops and round sardinella Sardinella aurita (Gökçe et al. 2016). Similarly, another fisher (area of Kavala) reported that whenever dolphin depredation is intense he chooses to change to a different gear (e.g. set longlines) and move to another fishing ground, where interactions are fewer or absent.

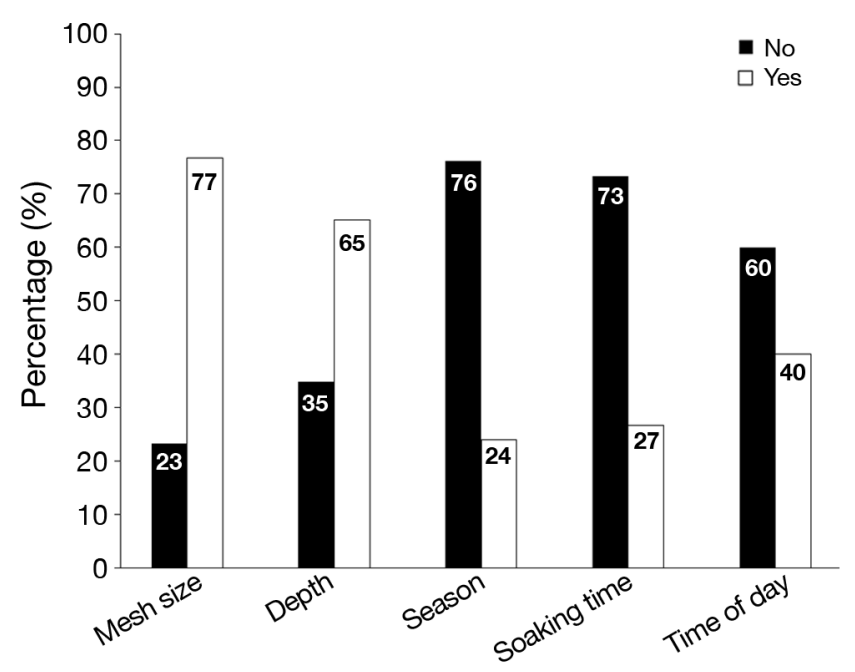

Fig. 2. Main factors perceived to be affecting depredation frequency according to the empirical knowledge shared by fishers of the northern Aegean Sea (mesh size: $\mathrm{n}=113$; depth: $\mathrm{n}=113$; season: $\mathrm{n}=71$; soaking time: $\mathrm{n}=15$; time of day: $\mathrm{n}=25$ )

\section{Preferred prey of, and depredation by, dolphins}

According to fishers, dolphins prey on a variety of demersal species such as red mullets, common sole, European hake, common dentex Dentex dentex, flathead grey mullet Mugil cephalus, bogue and even anglerfishes (Lophius spp.), and pelagic species, such as European barracuda Sphyraena sphyraena, European pilchard, picarel Spicara smaris and round sardinella. In contrast, dolphins were generally not reported to feed on scorpionfishes (Scorpaena spp.), caramote prawn and rays (Raja spp.). All fishers confirmed that incidental catches of dolphins in static nets are very rare, 3 of them admitting to having caught dolphins in their nets once, of which all but 1 were released alive.

According to fishers, the factors they empirically consider to be affecting depredation were mesh size, target species, depth and net concentration (Fig. 2). Specifically, they claimed that nets targeting red mullets were the most heavily depredated due to dolphin preference for the species (Rocklin et al. 2009).

Additionally, nets with small mesh size were considered prone to high depredation due to their lower selectivity, i.e. these nets were catching many individuals of a variety of species. Depredation was reported to be less frequent in deeper waters, and specifically at depths exceeding $130 \mathrm{~m}$. Lastly, high net concentration over a fishing ground was also reported by the fishers to attract dolphins in the vicinity. These reports are confirmed by 2 recent surveys, one on the factors that affect dolphin depredation frequency in the northern Aegean coastal fishery, where indeed mesh sizes smaller than $26 \mathrm{~mm}$ and waters less than $60 \mathrm{~m}$ deep were linked to high depredation probability (Pardalou \& Tsikliras unpublished data), and the other on the number of recorded damage events on different sets of gill nets and trammel nets deployed at various depth strata during a net selectivity experiment, where there was a diminishing trend with increasing depth and mesh size (Pardalou et al. unpublished data).

\section{Effect of gear characteristics and fishing tactics}

According to the fishers, demersal gill and trammel nets are the gears that are most depredated by dolphins, a pattern that has been reported in the literature (Lauriano et al. 2009, Bearzi et al. 2011, Goetz et al. 2014). Bottom-set nets act as 'supermarkets' entangling a variety of potential prey, among which dolphins take the most nutritious (Harwood 1992). 
This behaviour is in accordance with fishers' accounts that dolphins select their prey ('picky choosers'), depredating commercially important high-quality fish.

Fishers reported that nets targeting red mullets, common sole and European hake were most likely to be depredated by dolphins, similarly to relevant studies in other areas of the Mediterranean (Lauriano \& Bruno 2007, Gazo et al. 2008, Blasi et al. 2015). Indeed, bottlenose dolphins primarily feed on demersal and benthopelagic fish mainly concentrated at depths between 50 and $200 \mathrm{~m}$ (Blanco et al. 2001). For gears targeting other species, factors such as mesh size and deployment depth were reported to affect depredation (Fig. 2). Specifically, fishers reported that larger mesh sizes or/and higher depths showed decreased depredation/damage events. As dolphin occurrence is mainly driven by food availability and distribution, related anthropogenic activities such as fishing and fish farming may affect depredation (Azzellino et al. 2008, Blasi et al. 2015, Bonizzoni et al. 2016).

Commercially important fish species, which are also included in the diet of bottlenose and common dolphins, are mainly restricted to shallow waters, within the $200 \mathrm{~m}$ contour in the Mediterranean Sea (Lleonart \& Maynou 2003). Consequently, the majority of coastal fishers operate in waters less than $100 \mathrm{~m}$ and close to the coast, which is also the case for Greek waters (Adamidou 2007).

Soaking time, season and time of day were not indicated by the fishers as potential factors that would affect depredation frequency on nets (Fig. 2). Indeed, in a study in the Balearic Islands, soaking time was not among the important factors that affect dolphin depredation (Brotons et al. 2008), but seasonal and diel variation in the feeding behaviour of bottlenose dolphins from nets has been reported elsewhere (Brotons et al. 2008, Pennino et al. 2015).

Three fishers reported that after days of inactivity (e.g. inactive due to bad weather conditions or low market prices), dolphin depredation was initially scarce, a behaviour that has also been reported in another study of dolphin-fishery interactions in Asinara Island (north-western Sardinia: Lauriano et al. 2004).

\section{Optimal foraging theory}

According to optimal foraging theory (MacArthur \& Pianka 1966) an animal enhances its individual fitness by optimizing its foraging behaviour in terms of efficiency (net energy gain). Dolphins exhibit forag- ing plasticity and use various foraging strategies to cover their cost of living (Nowacek 2002). Dolphins have developed various foraging strategies and specializations to maximize their foraging efficiency (Torres \& Read 2009). The development of new foraging strategies is a dynamic process, thus dolphins have also learned to exploit human activities and most importantly fishing operations, by feeding from discards and nets at low energy cost (Reeves et al. 2001, Lauriano et al. 2004, Rocklin et al. 2009).

Similarly, fishers adapt their fishing behaviour and tactics aiming to maximize their economic gains, mainly driven by dynamic market forces, given that at present, the currency upon which hunting tactics are decided has changed from energy to money. Those that focus on short-term economic gain without any provision for the future continue to unsustainably utilize common natural resources and try to live their myth of 'free lunch' (Brooks 2006).

Acknowledgements. We thank the coastal fishers who shared their experience and Donna Dimarchopoulou for her comments on a previous version of the manuscript. Useful and rare material on dolphins and interactions with fishers in Greece is available online by Thanassis Vembos (www. vembos.gr).

\section{LITERATURE CITED}

Adamidou A (2007) Commercial fishing gears and methods used in Hellas. In: Papaconstantinou C, Zenetos A, Vassilopoulou V, Tserpes G (eds) State of Hellenic fisheries. Hellenic Centre for Marine Research, Athens, p 118-131 Anonymous (1989) Notes. Nature 40:401-402

Azzellino A, Gaspari S, Airoldi S, Nani B (2008) Habitat use and preferences of cetaceans along the continental slope and the adjacent pelagic waters in the western Ligurian Sea. Deep-Sea Res 55:296-323

*Barros NB, Wells RS (1998) Prey and feeding patterns of resident bottlenose dolphins (Tursiops truncatus) in Sarasota Bay, Florida. J Mammal 79:1045-1059

* Bearzi G, Holcer D, Notarbartolo-di-Sciara G (2004) The role of historical dolphin takes and habitat degradation in shaping the present status of northern Adriatic cetaceans. Aquat Conserv 14:363-379

Bearzi G, Agazzi S, Gonzalvo J, Bonizzoni S, Costa M, Petroselli A (2010) Biomass removal by dolphins and fisheries in a Mediterranean Sea coastal area: Do dolphins have an ecological impact on fisheries? Aquat Conserv 20:549-559

Bearzi G, Bonizzoni S, Gonzalvo J (2011) Dolphins and coastal fisheries within a marine protected area: mismatch between dolphin occurrence and reported depredation. Aquat Conserv 21:261-267

Berkes F, Anat H, Esenel M, Kişlahoğlou M (1979) Distribution and ecology of Monachus monachus on Turkish coasts. In: Ronald K, Duguy R (eds) First international conference on the Mediterranean monk seal. Pergamon Press, Oxford, p 113-127 
Bevilacqua AHV, Carvalho AR, Angelini R, Christensen V (2016) More than anecdotes: fishers' ecological knowledge can fill gaps for ecosystem modelling. PLOS ONE 11:e0155655

Blanco C, Salomón O, Raga JA (2001) Diet of the bottlenose dolphin (Tursiops truncatus) in the western Mediterranean Sea. J Mar Biol Assoc UK 81:1053-1058

Blasi MF, Giuliani A, Boitani L (2015) Influence of trammel nets on the behaviour and spatial distribution of bottlenose dolphins (Tursiops truncatus) in the Aeolian Archipelago, Southern Italy. Aquat Mamm 41:295-310

Bonizzoni S, Bearzi G, Santostasi NL, Furey NB, Valavanis VD, Würsig B (2016) Dolphin depredation of bottomset fishing nets in the Gulf of Corinth, Mediterranean Sea. In: Freitas L, Ribeiro C (eds) Into the deep: research and conservation on oceanic marine mammals. Proc 30th Ann Conf Eur Cetacean Soc, Madeira (Portugal), p 68

Bosc E, Bricaud A, Antoine D (2004) Seasonal and interannual variability in algal biomass and primary production in the Mediterranean Sea, as derived from 4 years of SeaWiFS observations. Global Biochem Cycles 18: GB1005

Bowen WD, Lidgard D (2013) Marine mammal culling programs: a review of effects on predator and prey populations. Mammal Rev 43:207-220

Brooks RJ (2006) The free lunch: myths that direct conservation policy and the natural laws that constrain it. In: Lavigne DM (ed) Gaining ground: in pursuit of ecological sustainability. IFAW, Guelph, ON, p 243-261

Brotons JM, Grau AM, Rendell L (2008) Estimating the impact of interactions between bottlenose dolphins and artisanal fisheries around the Balearic Islands. Mar Mamm Sci 24:112-127

* Cañadas A, Sagarminaga R, García-Tiscar S (2002) Cetacean distribution related with depth and slope in the Mediterranean waters off southern Spain. Deep-Sea Res 49:2053-2073

Cox TM, Read AJ, Swanner D, Urian K, Waples D (2003) Behavioural responses of bottlenose dolphin, Tursiops truncatus, to gillnets and acoustic alarms. Biol Conserv 115:203-212

Crnkovic D (1958) The dolphin problem. Morsko Ribarstvo 10:12-14

Cucknell AC, Frantzis A, Boisseau O, Romagosa M and others (2016) Harbour porpoises in the Aegean Sea, Eastern Mediterranean: the species' presence is confirmed. Mar Biodivers Rec 9:72

* Díaz López B (2006) Interactions between Mediterranean bottlenose dolphins (Tursiops truncatus) and gillnets off Sardinia, Italy. ICES J Mar Sci 63:946-951

* Dimarchopoulou D, Stergiou KI, Tsikliras AC (2017) Gap analysis on the biology of Mediterranean marine fishes. PLOS ONE 12:e0175949

Đuroviç M, Holcer D, Joksimović A, Mandić M, Fortuna C, Ikica Z, Vuković V (2017) Cetaceans in the Boka Kotorska Bay. In: Joksimović A, Djuroviç M, Semenov AV, Zonn IS, Kostianoy AG (eds) The Boka Kotorska Bay environment. Handb Environ Chem 54:411-438

European Commission (2014) Common Fisheries Registry (CFR). https://goo.gl/QqRUK5 (accessed 07/03/2014)

Frantzis A (2007) Fisheries interactions with cetacean species in Hellas. In: Papaconstantinou C, Zenetos A, Vassilopoulou V, Tserpes G (eds) State of Hellenic fisheries. Hellenic Centre for Marine Research, Athens, p 274-278
Frantzis A (2009) Cetaceans in Greece: present status of knowledge. Initiative for the Conservation of Cetaceans in Greece, Athens

* Gaspare L, Byceson I, Kulindwa K (2015) Complementarity of fishers' traditional ecological knowledge and conventional science: contributions to the management of groupers (Epinephelinae) fisheries around Mafia Island, Tanzania. Ocean Coast Manag 114:88-101

*Gazo M, Gonzalvo J, Aguilar A (2008) Pingers as deterrents of bottlenose dolphins interacting with trammel nets. Fish Res 92:70-75

* Goetz S, Read FL, Begoña Santos M, Pita C, Pierce GJ (2014) Cetacean-fishery interactions in Galicia (NW Spain): results and management implications of a face-to-face interview survey of local fishers. ICES J Mar Sci 71: $604-617$

* Gökçe G, Bozaoğlu AS, Eryaşar AR, Özbilgin H (2016) Discard reduction of trammel nets in the northeastern Mediterranean prawn fishery. J Appl Ichthyol 32:427-431

* Gonzalvo J, Giovos I, Moutopoulos DK (2015) Fishermen's perception on the sustainability of small-scale fisheries and dolphin-fisheries interactions in two increasingly fragile coastal ecosystems in western Greece. Aquat Conserv 25:91-106

* Harwood J (1992) Assessing the competitive effects of marine mammal predation of commercial fisheries. S Afr J Mar Sci 12:689-693

Johannes RE, Freeman MMR, Hamilton RJ (2000) Ignore fishers' knowledge and miss the boat. Fish Fish 1: 257-271

Kastelein RA, Jennings N, Verboom WC, de Haan D, Schooneman NM (2006) Differences in the response of a striped dolphin (Stenella coeruleoalba) and a harbour porpoise (Phocoena phocoena) to an acoustic alarm. Mar Environ Res 61:363-378

Kraus S (1999) The once and future ping: challenges for the use of acoustic deterrents in fisheries. Mar Technol Soc J 33:90-93

Lauriano G, Bruno S (2007) A note on the acoustic assessment of bottlenose dolphin behaviour around fishing gears in the Asinara Island National Park, Italy. J Cetacean Res Manag 9:137-141

Lauriano G, Fortuna GM, Moltedo G, Notarbartolo-di-Sciara G (2004) Interactions between common bottlenose dolphins (Tursiops truncatus) and the artisanal fishery in Asinara Island National Park (Sardinia): assessment of catch damage and economic loss. J Cetacean Res Manag 6:165-173

* Lauriano G, Caramanna L, Scarnò M, Andaloro F (2009) An overview of dolphin depredation in Italian artisanal fisheries. J Mar Biol Assoc UK 89:921-929

Lleonart J, Maynou F (2003) Fish stock assessments in the Mediterranean: state of the art. Sci Mar 67 (Suppl 1): 37-49

米López A, Pierce GJ, Santos MB, Gracia J, Guerra A (2003) Fishery by-catches of marine mammals in Galician waters: results from on-board observations and an interview survey of fishermen. Biol Conserv 111:25-40

MacArthur RH, Pianka ER (1966) On optimal use of a patchy environment. Am Nat 100:603-609

*Maynou F, Sbrana M, Sartor P, Maravelias Ch and others (2011) Estimating trends of population decline in longlived marine species in the Mediterranean Sea based on fishers' perceptions. PLOS ONE 6:e21818,

Milani CB, Vella A, Vidoris P, Christidis A, Koutrakis E 
(2013) Cetacean distribution in the Thracian Sea (North Aegean Sea, Greece) related with fishing activities. In: Sá E (ed) Interdisciplinary approaches in the study of marine mammals. Proc 27th Ann Conf Eur Cetacean Soc, Setuba, Spain, p 170

Mitra S, Koutrakis E, Clark T, Milani C (2001) Cetacean interaction with small scale coastal fisheries: implications for conservation and damage limitation in the Northern Aegean, Greece. In: Evans PGH, O'Boyle E (eds) European research on cetaceans. Proc 15th Ann Conf Eur Cetacean Soc, Rome, Italy, p 39

Nowacek DP (2002) Sequential foraging behaviour of bottlenose dolphins, Tursiops truncatus, in Sarasota Bay, FL. Behaviour 139:1125-1145

Papaconstantinou C, Farrugio H (2000) Fisheries in the Mediterranean. Mediterr Mar Sci 1:5-18

* Pennino MG, Rotta A, Pierce GJ, Bellido JM (2015) Interaction between bottlenose dolphin (Tursiops truncatus) and trammel nets in the Archipelago de La Maddalena, Italy. Hydrobiologia 747:69-82

Piroddi C, Bearzi G, Gonzalvo J, Christensen V (2011) From

Editorial responsibility: Darryl Macer,

Scottsdale, Arizona, USA common to rare: the case of the Mediterranean common dolphin. Biol Conserv 144:2490-2498

Reeves RR, Read AJ, Notarbartolo-di-Sciara G (2001) Report of the workshop on interactions between dolphins and fisheries in the Mediterranean: evaluation of mitigation alternatives. Instituto Centrale per la Ricerca Applicata al Mare, Rome

Rocklin D, Santoni MC, Culioli JM, Tomasisni JA, Pelletier D, Mouillot D (2009) Changes in the catch composition of artisanal fisheries attributable to dolphin depredation in a Mediterranean marine reserve. ICES J Mar Sci 66: 699-707

Stergiou KI, Moutopoulos DK, Tsikliras AC (2007) Spatial and temporal variability in Hellenic marine fisheries landings. In: Papaconstantinou C, Zenetos A, Vassilopoulou V, Tserpes G (eds) State of Hellenic fisheries. Hellenic Centre for Marine Research, Athens, p 141-150

Torres LG, Read AJ (2009) Where to catch a fish? The influence of foraging tactics on the ecology of bottlenose dolphins (Tursiops truncatus) in Florida Bay, Florida. Mar Mamm Sci 25:797-815

Submitted: June 18, 2017; Accepted: November 15, 2017 Proofs received from author(s): January 25, 2018 